\title{
Raising The Bar In Troubled Times: Business Goals Of Our Future Leaders
}

Stephen C. Betts, (e-mail: bettss@wpunj.edu), William Paterson University Virginia Taylor, (e-mail: taylorv@wpunj.edu), William Paterson University

\begin{abstract}
In times of international terrorism, corporate corruption and economic uneasiness, it is easy to become cynical and jaded regarding the ethical, legal and social responsibilities of American business. A survey of management students however provides cause for optimism. According to the survey they perceive responsibilities towards employees and society, respecting ethical norms and staying within the law to be 'moderately' to 'very' important goals to the typical American business person and consider these same goals 'very' to 'of utmost' importance to themselves. Over the period of the study 'personal wealth' and 'honor, face, reputation' have decreased in importance while 'patriotism and national pride' has increased. This indicates that despite world events our future business leaders intend to raise the bar regarding issues of corporate performance and social responsibility.
\end{abstract}

\section{Introduction}

C our rapidly changing world wondrous promise and opportunity stands in sharp contrast to acts of international terrorism and corporate corruption. Visible examples of cultural unrest, corporate shortsightedness and personal greed it is easy to be pessimistic about the future. In this paper we examine the business goals and perceptions of our future leaders. We report on a survey given to several groups of business students, some before the tragedy of 9/11/03 and some after. First the survey is explained, followed by a description of the methods and data analysis. This is followed by a discussion of the results. The paper concludes with the limitations of the study and some suggestions for further research.

\section{The Survey Instrument}

Geert Hofstede presented a 'business goals' instrument at the International Business \& Society conference in Paris, France in June of 1999. He encouraged others to freely use it and provide him with the results and feedback. His one page survey was designed for cross-cultural comparisons of perceived business goals. The survey contains fifteen potential business goals, and with a five point scale of importance (see Tables 1,2). The subjects are asked what they perceive to be the importance of each goal to the 'typical businessperson' in their country. They are also asked what importance they would personally assign to each of the goals if they were successful businesspersons in a few years. The survey concluded with a few demographic questions.

Table 1 - Response Scale

\begin{tabular}{|l|l|}
\hline 1 & of utmost importance \\
\hline 2 & very important \\
\hline 3 & of moderate importance \\
\hline 4 & of little importance \\
\hline 5 & of very little or no importance \\
\hline
\end{tabular}


Table 2 - Survey Items and Mean Responses

\begin{tabular}{|l|c|c|c|c|}
\hline & \multicolumn{2}{|c|}{ Typical Businessperson } & \multicolumn{2}{c|}{ Self } \\
\hline Survey Items & pre 9/11 & post 9/11 & pre 9/11 & post 9/11 \\
\hline continuity of the business & 1.59 & 1.70 & 1.48 & 1.53 \\
\hline creating something new & 2.24 & 2.17 & 1.88 & 1.90 \\
\hline family interests (like jobs for relatives) & 3.06 & 3.00 & 2.72 & 2.50 \\
\hline game and gambling spirit & 3.29 & 3.24 & 3.19 & 3.19 \\
\hline growth of the business & 1.51 & 1.53 & 1.43 & 1.44 \\
\hline honor, face, reputation & 1.63 & $2.01 * * *$ & 1.30 & $1.46^{*}$ \\
\hline patriotism, national pride & 2.84 & $2.60 *$ & 2.61 & $2.20^{* * *}$ \\
\hline personal wealth & 1.55 & 1.90 & 1.60 & $1.77 *$ \\
\hline power & 1.75 & 1.84 & 1.97 & 2.07 \\
\hline this year's profits & 1.57 & 1.66 & 1.61 & 1.63 \\
\hline profits 10 years from now & 1.92 & 2.10 & 1.70 & 1.80 \\
\hline respecting ethical norms & 2.43 & 2.60 & 1.93 & 1.85 \\
\hline responsibility towards employees & 2.16 & $2.45 * *$ & 1.58 & $1.73 *$ \\
\hline responsibility towards society in general & 2.42 & $2.66 *$ & 1.95 & 2.01 \\
\hline staying within the law & 1.98 & $2.27 *$ & 1.65 & 1.72 \\
\hline
\end{tabular}

significance of difference between pre $9 / 11$ and post $9 / 11 * * * p<.001, * * p<.01, * p<.1$

\section{Research Methods, Analysis and Results}

The survey was distributed to undergraduate business majors in several class sections in a large eastern university. A total of 377 respondents returned the completed survey. The sample sex demographic was 53.2\% male. The average age of the respondents was 24.6 years. These students also indicated an average full time work experience of 8.5 years.

Factor analysis (principle components, vari-max rotation) did not reveal factors that were consistent over the various situations (typical businessperson/self, pre/post 9/11). This is interesting because three factors representing 'social responsibility', 'corporate success' and 'personal gain' were found in the past using only pre 9/11 data (Taylor \& Betts, 2002).

Table 3 - Standard Deviations (significant differences only)

\begin{tabular}{|c|c|c|c|}
\hline & \multicolumn{3}{|c|}{ Typical Businessperson } \\
\hline Survey Items & pre $9 / 11$ & post $9 / 11$ & difference \\
\hline family interests (like jobs for relatives) & 1.11 & 0.98 & $-0.13 *$ \\
\hline honor, face, reputation & 0.75 & 1.04 & $0.29 *$ \\
\hline patriotism, national pride & 0.96 & 1.06 & $0.10 *$ \\
\hline power & 0.75 & 0.90 & $0.15 *$ \\
\hline \multirow[t]{2}{*}{ responsibility towards employees } & 0.87 & 1.00 & $0.13 * *$ \\
\hline & \multicolumn{3}{|c|}{ Self } \\
\hline Survey Items & pre $9 / 11$ & post $9 / 11$ & difference \\
\hline honor, face, reputation & 0.51 & 0.60 & $0.09 * * *$ \\
\hline personal wealth & 0.64 & 0.89 & $0.25 * *$ \\
\hline responsibility towards employees & 0.69 & 0.74 & $0.05 *$ \\
\hline
\end{tabular}

Of the 377 surveys, 88 were completed prior to the 9/11/03 tragedy, and 289 in subsequent semesters. Table 1 shows the mean responses for before and after $9 / 11$, as well as the significance of the difference (means test). The responses were significantly lower for the perceived importance to the typical businessperson of 'honor, face, reputation', 'responsibility towards employees', 'responsibility towards society in general' and 'staying within the law', and significantly lower importance for the individual for 'honor, face, reputation', 'responsibility towards 
employees' and 'personal wealth'. 'Patriotism, national pride' was significantly higher for both typical businessperson and the individual. The variance was significantly higher for several survey items as is reported in Table 3 .

Table 4 - Paired-Sample T-test of Business

Goals means Test between Typical and Subject (significant differences only)

\begin{tabular}{|c|c|c|c|}
\hline Survey item & Typical & Self & difference \\
\hline creating something new & 2.20 & 1.89 & $0.31 * * *$ \\
\hline family interests (like jobs for relatives) & 3.04 & 2.56 & $0.48 * * *$ \\
\hline honor, face, reputation & 1.94 & 1.41 & $0.53 * * *$ \\
\hline patriotism, national pride & 2.67 & 2.29 & $0.39 * * *$ \\
\hline power & 1.81 & 2.03 & $-0.22 * * *$ \\
\hline respecting ethical norms & 2.56 & 1.88 & $0.68 * * *$ \\
\hline responsibility towards employees & 2.38 & 1.68 & $0.70 * * *$ \\
\hline responsibility towards society in general & 2.60 & 2.01 & $0.59 * * *$ \\
\hline staying within the law & 2.18 & 1.66 & $0.52 * * *$ \\
\hline
\end{tabular}

The values of the perceived importance for today's typical businessperson and the equivalent scales for the subjects' personal business goals were tested using a paired-sample T-test . Results are presented in Table 4. The data indicates that many business goals are significantly more important goals for the subjects themselves than for the typical businessperson. The notable exception is power is significantly less important for the subjects. The largest differences were for goals representing various aspects of social responsibility.

Table 5 - Correlations between Age/Years

of Employment and Business Goals (significant correlations only)

\begin{tabular}{|l|c|c|c|c|}
\hline & \multicolumn{2}{|c|}{ Age } & \multicolumn{2}{c|}{ Years Employed } \\
\hline Survey item & Typical & Self & Typical & Self \\
\hline family interests (like jobs for relatives) & & $0.11 *$ & & $0.12 *$ \\
\hline game and gambling spirit & $0.10 *$ & & & \\
\hline growth of the business & $-0.11 *$ & & $-0.10^{*}$ & $0.18^{* * *}$ \\
\hline power & & $0.16 * *$ & $0.11 *$ & $-0.15 * *$ \\
\hline respecting ethical norms & & $-0.12 *$ & & $-0.12 *$ \\
\hline responsibility towards employees & & & $0.09 *$ & $-0.12 *$ \\
\hline responsibility towards society in general & & & & $-0.10 *$ \\
\hline staying within the law & & $-0.09 *$ & & \\
\hline
\end{tabular}

significance of correlation $* * * p<.001, * * p<.01, * p<.1$

Differences in responses associated with demographic and personal characteristics of the subjects were also explored. Specifically the age, number of years employed and gender of the subjects were examined. For age and number of years employed, correlation coefficients are reported in Table 5. A positive correlation means that increasing age or work experience is associated with decreasing rated importance of the goal. The highest correlations represented an increasing importance for respecting ethical norms and a decreasing importance of power as age and experience increases. An ANOVA was performed to examine gender based differences, as reported in Table 6. A positive difference on the table indicated that males rated the item as more important. One $t$ noticeable gender based difference is that female subjects rated many items as more important, both to the typical businessperson and to themselves, with individual power as an exception. The most significant differences were in the areas of responsibilities and ethics, where females respondents rated them as more important personal business goals. 
Table 6 - Gender Differences (significant differences only)

\begin{tabular}{|l|c|c|c|}
\hline & \multicolumn{3}{|c|}{ Typical Businessperson } \\
\hline Survey item & Female & Male & Difference \\
\hline continuity of the business & 1.59 & 1.74 & $-0.15^{*}$ \\
\hline honor, face, reputation & 1.81 & 2.01 & $-0.20^{*}$ \\
\hline patriotism, national pride & 2.49 & 2.81 & $-0.32 * *$ \\
\hline profits 10 years from now & 1.96 & 2.15 & $-0.14^{*}$ \\
\hline responsibility towards society in general & 2.43 & 2.76 & $-0.32 * * *$ \\
\hline staying within the law & 2.10 & 2.29 & $-0.19 *$ \\
\hline & \multicolumn{3}{|c|}{ Self } \\
\hline Survey item & Female & Male & Difference \\
\hline continuity of the business & 1.45 & 1.58 & $-0.14 *$ \\
\hline patriotism, national pride & 2.14 & 2.42 & $-0.29 * *$ \\
\hline power & 2.16 & 1.95 & $0.21 *$ \\
\hline respecting ethical norms & 1.69 & 2.02 & $-0.33^{* * *}$ \\
\hline responsibility towards employees & 1.57 & 1.80 & $-0.23 * *$ \\
\hline responsibility towards society in general & 1.84 & 2.13 & $-0.29 * * *$ \\
\hline staying within the law & 1.52 & 1.87 & $-0.35 * * *$ \\
\hline significance of difference between genders $* * * p<.001, * * p<.01, * p<.1$ & \\
\end{tabular}

\section{Discussion}

The students generally rated the business goals as of moderate or higher importance. The finding that they consider many goals more important than they perceive the typical business does is a cause for optimism. It shows intent to establish higher standards. The exception was 'power' which showed the opposite tendency. Along with raising the bar it is comforting to know that our students aren't power hungry, rating it lower than what they perceive as typical.

The comparison of attitudes before and after $9 / 11$ is confusing. The increase in 'patriotism, national pride' is most likely due to the terrorist attacks and subsequent military actions. This is not to say that the patriotic views have grown out of proportion, because they still are rated less important than patriotism. The decrease in "honor, face and reputation' may be a sign of a realignment of priorities. What is more difficult to explain is the decrease in the importance of responsibility - whether to employees, society in general or to obeying the law. Perhaps the economic downturn and rash of corporate scandals has left students rudderless and cynical. Another possibility is that upon reflection students realize that there are more things to life than 'business goals' and therefore consider them less important. Even so, after 9/11 the majority of business goals were still rated as between 'very important' and 'of utmost importance'. The finding that there was a significantly wider variance post $9 / 11$ indicates that the reaction to world events has not been uniform. This might be reflecting differences in sensitivity to events or differences in awareness.

Age and work experience showed an interesting pattern. As age and experience increased there is an increase in the importance of respecting ethical norms and decrease for power in both for typical business person and self. The trend might indicate a move from a self-focused world view to a more inclusive view. The finding that the trend is present for both typical and self indicates a general change in perspective. With age and experience, comes a realization that power-seeking is generally not that important to the world and therefore not that to themselves either. Similarly, is a somewhat encouraging realization that ethical standards are important.

The observed gender differences centered around the importance of social responsibility related issues. Specifically, female respondents reported that these issues were more important as their own personal goals that male respondents. The greater difference at the individual level indicates that both genders have a similar view of the business world, but women intend on 'raising the bar' higher than their male counterparts. 


\section{Limitations and Future Research}

The survey was designed for cross-cultural comparisons and we report on a single sample from one part of one country. The low average and limited range of the age of the subjects also brings into question the degree to which these finding can be generalized to a more general working population.

This work is largely descriptive in nature and therefore is limited in its contribution. It is important step towards the development of a theoretical framework within which business goals can be examined. Covariates, both antecedents and outcomes, can be proposed for the business goals once the goals are somehow framed. The theoretical underpinnings of the specific goals also need to be examined. Are there precedents in the literature that can be brought in, perhaps from another field? A final issue is the practical value of the research. Once a conceptual framework is adopted and relationships proposed, then attention needs to be called to the link between theory and practice.

Suggestions as to further empirical work largely depend on the development of theory. The analytical frame and choice of covariates will dictate the study design and analytical techniques. The development of the theory regarding the goals themselves will undoubtedly lead to refinements in the survey instruments. It is also advisable to seek out others who have used this instrument to compare results. This study takes a first step in both understanding the perceptions and plans of our future leaders and in exploring the effects of recent events. It also sends an optimistic message through the goals of our future leaders. We intend on continuing this work in order to prescribe actions that enable our managers to develop and effectively pursue business goals in the best interest of all.

\section{References}

Available upon request

Notes 
Notes 